Jerem van Duijl, Leiden University

\title{
Collecting Property for the Founding of a Teutonic House in Utrecht (1218-1235) Introduction
}

Utrecht was the medieval capital of the Low Countries north of the Rhine, where it was the most populous city until late medieval commercial growth turned centres of trade like Amsterdam into boomtowns. Ottonian and Salian emperors frequently visited Utrecht. Two of them, Conrad II and Henry V, died there. Their intestines were buried in St. Martin's Cathedral. ${ }^{1}$ Most importantly, Utrecht was the seat of a bishop and, therefore, a religious centre. Drawings of the city sky line in the sixteenth century show many towers of churches and monasteries surrounding the tall cathedral. This religious importance explains the presence of two military orders: both the Hospitallers and the Teutonic Order had their regional headquarters in Utrecht.

The Hospitallers appeared first, although their earliest history in the city is unknown. They are probably mentioned in a charter from 1122 , although this is open to debate and the year seems quite early. In the early sixteenth century, their convent was demolished, and their archives destroyed, possibly by a fire that struck the convent in 1518 , leaving us with a fragmented preservation of sources. ${ }^{2}$ The contrast between the Hospitallers and the

\footnotetext{
${ }^{1}$ H.C. Hazewinkel, 'De keizersgraven in den Dom', in Jaarboekje van “Oud-Utrecht” (1929), pp.25-34; P. Borst, A. de Groot, J.G. Jonker-Klijn and R. Roks, Graven en begraven in de Dom van Utrecht (Bunnik, 1997).

2 J.M. van Winter, 'Les seigneurs de Sainte-Catharine à Utrecht. Les premiers Hospitaliers au nord des Alpes', in Autour de la première croisade. Actes du Colloque de la Society for the Study of the Crusades and the Latin East (Clermond-Ferrand, 22-25 juin 1995), ed. Michel Balard (Paris, 1996), pp. 239-246; Idem, 'Sources concerning the Hospitallers of St. John in the Netherlands, $14^{\text {th }}-18^{\text {th }}$ centuries', Studies in the History of Christian Thought, 80 (Leiden, Boston and Cologne, 1998), pp. 15-16.
} 
Teutonic Knights could not be sharper. The Teutonic House just outside the city walls was torn down in 1345, when the count of Holland laid siege on the city. It was rebuilt in the following years at a safer location within the walls. Since then, it has weathered all storms of time, except for the church that collapsed when hurricane-force winds hit the city in August 1674. The commandry's archives have been preserved in exceptionally good shape up to today. In his article that contributes to the lively historiography about the history of the Teutonic House of Utrecht, R. Stapel rightly classifies them as the richest of all the archives of Teutonic Order bailiwicks in the Holy Roman Empire. ${ }^{3}$

However, these fortunate circumstances inevitably also biased our knowledge of the convent towards roughly the fifteenth and sixteenth centuries. From the many late medieval sources we just mentioned, we get the impression that the brethren at the time already had a vague and sometimes erroneous understanding of the earliest history of their institution, or the "old Teutonic House" as they called it. Its ruins are depicted as a remembrance of long bygone days in a drawing of the city in $1590 .{ }^{4}$ The small road that ran along it in the sixteenth century was known as the Karweg, which translates into cart road. This name probably caused a misunderstanding when, in the 1530s, a cartulary of the convent's possessions was created. A copy of a charter of 1219, the oldest one to be found in the cartulary, bears the heading: "Lord Sweder of Dingden has given [...] the Teutonic Order his manor [...] at the cart road." In fact, Sweder did not mention any cart road in the charter. He

\footnotetext{
${ }^{3}$ R.J. Stapel, 'Priests in the military orders. A prosopographical survey of the priest-brethren in the Utrecht bailiwick of the Teutonic Order (1350-1600)', Analecta Theutonica. Studies for the History of the Teutonic Order, 1 (2014), pp. 102-103.

${ }^{4}$ Aernout van Buchel, Commentarius rerum quotidianarum, Universiteitsbibliotheek Utrecht Hs. 798 (Hs. 6 E 15), fol. $10 \mathrm{v}$.
} 
did, however, mention Lankarn, which surely must be read as Lankern, a hamlet nearby his hometown Dingden, close to the Rhine in Westphalia. In general, the number of copied documents in the cartulary rapidly decreases the further we go back in time. From the first half of the thirteenth century, only a few sources remain.

This scarcity was already a problem in about 1480, when a chronicle of the bailiwick's history was written as a supplement to a well-known chronicle of the Teutonic Order, in literature often called the "Jüngere Hochmeisterchronik." The narrative is interwoven with details from many charters and other primary sources that were consulted. This strengthens the message of the chronicle, which was to show the ancient traditions and the long continuity of the order and bailiwick. ${ }^{5}$ The account of the commandry's earliest history also gives this impression of a summary based on facts collected from archival material. It states that, in 1231 , Sweder of Dingden gave away all the land he owned nearby the city of Utrecht to the Order to enable the establishment of the Teutonic House there. However, a fact check shows several shortcomings in this account. For example, the author mentions Otto of Holland as the bishop at the time, where he should have named Willibrand of Oldenburg, who died in 1233. He also mentions Sweder's marriage to Beatrix of Wiltenburg, therewith implicitly explaining Sweder's presence in Utrecht by linking him to a well-known Utrecht family. Indeed, the name of his wife was Beatrix, but she was actually the daughter of Herman, Count of Lohn, a small county west of Dingden. ${ }^{6}$ Moreover, other parties that may have been involved in the founding of the Teutonic House are not mentioned. We read

\footnotetext{
${ }^{5}$ R.J. Stapel, The Late Fifteenth-Century Utrecht Chronicle of the Teutonic Order: Manuscripts, Sources, and Authorship (PhD thesis, Leiden, 2017), pp. 216, 269-287, 303, 308-311.

${ }^{6}$ Oorkondenboek van Gelre en Zutphen tot 1326 IV: Klooster Bethlehem bij Doetinchem, ed. E.J. Harenberg (The Hague, 1991), nos. 1223.12.32, 1230.09.28.
} 
nothing about other donations; nor are influential public persons like the bishop mentioned, as it was probably hard enough to make up a credible story based on the few charters that were present.

Still, this story has hardly ever been altered. The major addition in modern historiography is the important fact that there were two Sweders of Dingden to account for: one made his donation during the siege of Damietta in 1219 , and his son, with the same name, followed with a donation in 1231 . The latter did this to redeem his unfulfilled crusade vow. Furthermore, J.A. Mol notes that witnesses from Utrecht were present at the donation of Sweder Senior in 1219 , but he does not elaborate on this matter. ${ }^{7}$ The involvement of a wider public in the founding process of the House also arises from several charters from the 1220 s and especially the 1230 s. They include two transactions with the young convent. There is enough reason to re-examine the founding of the Teutonic House in Utrecht.

In the first part of this article, the donations of both Sweders are subject to a new critical interpretation. Special attention is paid to their careers and social network in Utrecht. From there we broaden our view to other parties involved, both by discussing charters that directly related to the Teutonic House in Utrecht and by paying attention to the context of developments within the bishopric of Utrecht, crusading expeditions, and the founding of other houses in the Low Countries. It appears that the founding of the Teutonic House of Utrecht was not the isolated act of a father and son, but rather a thoroughly planned campaign with many stakeholders and with connections to the Order's expansion elsewhere.

\footnotetext{
${ }^{7}$ J.A. Mol, 'Vechten of verplegen? Ontstaan en begintijd van het huis en de balije Utrecht van de Duitse Orde', in Vechten, bidden en verplegen. Opstellen over de ridderorden in de Noordelijke Nederlanden, ed. idem (Hilversum, 2011), p. 25.
} 


\section{The Changing Patronage Relations of a Borderlord}

Sweder of Dingden Senior could have participated in the siege of Damietta for several feudal lords during the Fifth Crusade. He possessed the right of high justice within his small lordship in fealty to the bishop of Müster. Dingden was located at the southwestern fringe of this bishopric. The count of Berg enfeoffed him with parts of a manor in Dieren, in the neighbouring county of Guelders. Adolf of Berg was a leading figure in Damietta, where he donated his Dieren manor from his deathbed to the Teutonic Order in June $1218 .{ }^{8}$ Sweder followed him the next year by donating his part of the manor. At the same time, he bestowed the Order with the aforementioned curia in Lankarn, and a small piece of land in Schalkwijk, near the city of Utrecht. ${ }^{9}$

These two donations show that Sweder Senior not only acted in line with his suzerain, but went further by proactively joining a wave of donations in the Low Countries during and in the wake of the Fifth Crusade. In 1219, Count William of Jülich gave generously. ${ }^{10}$ From September of the same year until 1225, a series of donations in Brabant and Flanders were made by members of the Berthout dynasty. ${ }^{11}$ This began with a donation

\footnotetext{
${ }^{8}$ ARDOBU II, no. 462; Urkundenbuch für die Geschichte des Niederrheins oder des Erzstifts Cöln, der Fürstenthümer Jülich und Berg, Geldern, Meurs, Kleve und Mark, und der Reichsstifte Elten, Essen und Werden II, ed. T.S. Lacomblet (Düsseldorf, 1846), no. 72.

${ }^{9}$ ARDOBU II, no. 463; Archief van de Ridderlijke Duitsche Orde Balije van Utrecht 1200-1811, ed. P.J.C.G. van Hinsbergen (Utrecht, 1982), no. 1718; Codex diplomaticus Ordinis Sanctae Mariae Theutonicorum I, ed. J.H. Hennes (Mainz, 1845), no. 35.

${ }^{10}$ Urkundenbuch für die Geschichte des Niederrheins II, nos. 82, 132.

${ }^{11}$ J.M. Powell, Anatomy of a Crusade 1213-1221 (Philadelphia, 1986), pp. 81-82; G. Croenen, Familie en macht. De familie Berthout en de Brabantse adel (Leuven, 2003), pp. 33-34, 38 n.60, 290-291.
} 
by the crusader Gillis Berthout, who was also the Lord of Oudenburg, and his wife Catharina. ${ }^{12}$ They were related to Count Arnold III of Loon, another participant in the crusade who, in 1220, together with his sister Mechteld, donated goods in Biesen. ${ }^{13} \mathrm{~A}$ last example that should not be left out is the donation of goods in and near Schelluinen by Theodore III, Lord of Altena in 1220. His small lordship of Altena was wedged between Brabant and Holland. Theodore was present in Damietta as well. We can classify him as belonging to the circle of confidants that collectively supported the Teutonic Order. This was apparent, for instance, by the performance of Walter Berthout, son of Guda of Loon, as first witness in a charter issued by Theodore in 1214. As well, his sister Sophie was married to Arnold of the Grimbergen branch of the Berthout dynasty. ${ }^{14}$

These closely related donations cannot be seen apart from the fact that many participants in the Fifth Crusade came from the Low Countries. Both are a result of the outcome of the conflict between the Holy Roman Emperor Otto IV and his rival Frederick II of the Hohenstaufen dynasty. Initially, Otto enjoyed major support in the Low Countries. But things became problematic after he was defeated in the battle of Bouvines in 1214 and Frederick was crowned as the Roman king one year later. Princes who had supported Otto now tried to switch to the Hohenstaufen side. To do that, existing alliances and patronage networks had to be re-evaluated, which caused social unrest. Count William of Holland, for example, was excommunicated by the pope when he changed sides from King John of

\footnotetext{
${ }^{12}$ De oorkonden van Pitsenburg, commanderij van de Duitse Ridderorde te Mechelen (1190-1794) I, ed. A. Jamees (Antwerpen, 1990), nos. 9-11.

${ }^{13}$ ARDOBU II, no. 489.

${ }^{14}$ T. Klaversma, 'De geslachten Altena en Horne tot ca. 1300', Publications de la Société Historique et Archéologique dans le Limbourg, 114 (1978), pp. 16, 26-28.
} 
England, who had supported Otto, to the French king. In his analysis of the crusade, James Powell convincingly argues that Pope Innocent III managed to pacify the region by letting the crusade be preached against an external enemy, whilst giving the crusaders an opportunity to regain their power. ${ }^{15}$ So, Count William was absolved from his excommunication in return for his participation. The bishop of Utrecht also travelled to the Holy Land with a delegation. When the crusade was over, multiple houses of the Teutonic Order were founded in the Low Countries by crusaders and their family members. As we have seen, this was the case in Flanders and Brabant, but also more to the North, such as in Schelluinen and Dieren. By collectively making donations to the Teutonic Knights, patronage and family networks were strengthened.

What also strikes us about these donations is that it was not the duke of Brabant, the count of Holland, or other prominent princes, who made them. Instead, the core of this network of donators consisted of nobles who wielded power over small lordships in the periphery of larger principalities. Such minor lords in frontier regions were a very common phenomenon in the late middle ages, although in various constellations. They existed, for instance, at the Anglo-Scottish border, Normandy, and between France and the Low Countries. ${ }^{16}$ In historiography, they are sometimes given the applicable umbrella term

\footnotetext{
${ }^{15}$ Powell, pp. 74-84.

${ }^{16}$ B. Holden, Lords of the Central Marches. English Aristocracy and the Frontier Society 1087-1265 (Oxford, 2008); H. Cools, 'Nobles on the borderline. The nobility of Picardy, Artois and Walloon Flanders and the Habsburg-Valois conflict, 1477-1529', in Secretum scriptorium. Lober alumnorum Walter Prevenier, ed. W. Prevenier, W. Blockmans, M. Boone and T. de Hemptinne (Leuven, 1999), p. 373; D. Power, The Norman Frontier in the Twelfth and Early Thirteenth Centuries (Cambridge, 2004), pp. 213-223; P.C.M. Hoppenbrouwers, Een middeleeuwse samenleving (Wageningen, 1992), pp. 3-15.
} 
'borderlords'. They ruled and defended their territories from a military stronghold, but for the preservation of their power they depended on the protection of a powerful neighbouring prince. The possibility of changing sides to another greater patron when the previous one tried to incorporate the lordship into his realm was essential.

Finding the patronage of a prince normally entailed becoming his vassal. Because of this, the social status of borderlords bears some resemblance to castellans. In principalities where the military elite, castellans, and other knights consisted of ministeriales, this vassalization could even go as far as giving up freedom by entering ministeriality. In practice, this did not mean descending down the social ladder. It was more a logical confirmation of the new feudal relation between a borderlord and his mighty patron, since becoming a knightly ministeriale entailed swearing fealty. Hence, we arrive at another development that was at stake, namely, the affiliation lesser nobles felt with knights. In these bellicose times, knights often fulfilled their classic feudal military duty, resulting in their rising status. Borderlords were among the first lesser nobles to call themselves milites as well, putting them at the forefront of the changing meaning of a knight, from the military profession to a noble title. Thus, after trying unsuccessfully to defend their lordship against the expanding power of the duke of Brabant by waging war and seeking rapprochement to the count of Flanders, as of the second half of the twelfth century, the Berthouts came to accept the duke of Brabant as their suzerain. In 1238, Walter IV Berthout, Lord of Mechelen, assigned all his allodia as one fief to the duke. ${ }^{17}$ In 1220 , Theodore of Altena, feeling similar pressure from

\footnotetext{
${ }^{17}$ Croenen, pp. 89-91, 235-239.
} 
the duke, sought the protection of the count of Holland by conferring to him his castrum and receiving it back as a fief. ${ }^{18}$

Sweder of Dingden Senior was a similar lesser nobleman with princely aspirations in a borderland. His territory was enclosed by the prince-bishopric of Münster, the small county of Lohn, and the larger counties of Cleves and Guelders. Halfway during the twelfth century, his ancestor Gerlach became a ministeriale of the bishop of Münster. ${ }^{19}$ Relations with this bishop seem to have become troublesome by the end of the century because Sweder Senior disappeared from witness lists of charters issued by the bishop; around 1200 , he took advantage of a chance to change sides to another patron. In 1197, Theodore of Are, who was from an important noble family in the Rhineland, became Bishop of Utrecht. He brought along relatives and other Rhinelandish and Westphalian confidants and installed them in influential positions, especially at Saint Martin's cathedral. His nephew, Otto of Lippe, was made the cathedral's provost, ${ }^{20}$ and became bishop in 1216 . Other relatives were given positions as regular canons. ${ }^{21}$ In 1208 , Theodore of Randerath was still canon in Cologne, and in 1217 he was canon of Saint Martin's cathedral of Utrecht. ${ }^{22}$ In his testament, he paid tribute to Bishop Theodore with a memory. ${ }^{23}$ According to the famous Cistercian novice

\footnotetext{
${ }^{18}$ Klaversma, pp. 28-30.

${ }^{19}$ F. Reigers, Beiträge zur Geschichte der Stadt Bocholt und ihrer Nachbarschaft (Bocholt, 1891), p. 119.

${ }^{20}$ Quedam narracio de Groninghe, de Thrente, de Covordia et de diversis aliis sub diversis episcopis

Traiectensibus, ed. H. van Rij, Middeleeuwse Studies en Bronnen, 1 (Hilversum, 1989), p. 35.

${ }^{21}$ U. Bader, Geschichte der Grafen von Are bis zur Hochstadenschen Schenkung (1246), Rheinisches Archiv, 107 (Bonn, 1979), pp. 349-350.

${ }^{22}$ OSU II, nos. 586, 645.

${ }^{23}$ Ibid., no. 1126 .
} 
master Caesarius of Heisterbach, a certain Gerlacus of Dingden was canon at Saint Martin's until $1216 .{ }^{24}$ His uncle Sweder Senior likely was also one of the immigrants. From 1200 onward, he was a prominent witness at charters issued by Bishop Theodore. ${ }^{25}$

This socio-political network reveals why Sweder Senior, in 1219, donated a piece of land in Utrecht to the Teutonic Order and why the first half of the witness list bears the names of ministeriales from Utrecht, like Andreas of Werkhoven and Ernst of Wulven. They were not important because of the size of the donated property in Utrecht; other parts of the donation were much larger. Rather, Sweder was attaching himself to the top of Utrecht's knightly ministeriales, and the affection was mutual. This was the first occasion at which an Utrecht ministeriale, Ernst, called himself dominus, a title that used to be reserved for nobles of "free" birth only. What we see here is the merger of the nobility below the level of magnates and ministeriales, which happened in Utrecht just as it was happening elsewhere in the Holy Roman Empire during the late twelfth and early thirteenth centuries. ${ }^{26}$ In the geopolitical landscape of the time, those ambitious ministeriales in particular could identify themselves with an order that was protected by both Otto IV and Frederick II, and stood under the leadership of Herman of Salza, who was born to a family of ministeriales. The event looks very similar to the donations of other crusaders from the Low Countries. In this context, we may assume Sweder Senior joined plans to found a settlement of the Teutonic Order in Utrecht.

\footnotetext{
${ }^{24}$ J.J. van Moolenbroek, Mirakels historisch. De exempels van Caesarius van Heisterbach over Nederland en de Nederlanders (Hilversum, 1999), pp. 31-34.

${ }^{25}$ OSU II, nos. 542, 581.

${ }^{26}$ P.H. Wilson, The Holy Roman Empire. A Thousand Years of Europe's History (Penguin edition; London, 2017), pp. 376, 383.
} 
If these plans existed, they were not implemented as fast as in the surrounding regions. Ernst of Wulven, the Utrecht ministeriale who witnessed Sweder's donation in Damietta, did not become a Teutonic Knight even though someone with the same name was marshal of the Teutonic Order in Acre in 1265, and was remembered in that office in a necrology that belonged to the bailiwick of Biesen. ${ }^{27}$ This Ernst probably was a descendent of the Ernst in Damietta because the latter remained a ministeriale when the Teutonic House was already established. Sweder Senior did not enter the Order either. He became a regular canon in the Bethlehem monastery in Guelders which, between 1276 and 1286, tried to join the Teutonic Order. ${ }^{28}$ By then, he was already long dead. When, in 1230 , Count Herman of Lohn handled a transaction with the monastery, he did this in remembrance of the diseased Sweder. ${ }^{29}$ The good relations between Count Herman and the Dingden family were also expressed by the marriage of Herman's daughter Beatrix with Sweder Junior. It was the younger Sweder who, in 1231 , stepped into the crusading footsteps of his father by redeeming his and his wife's unfulfilled crusade vow, with a donation to the Teutonic Order that directly led to the establishment of the Teutonic House in Utrecht. ${ }^{30}$

The charter is hard to interpret as it raises several questions. Firstly, we may ask if Sweder Junior donated enough to found the Teutonic House on his own. To provide a new convent with a steady source of income, the acquisition of a sizable estate would have been

\footnotetext{
${ }^{27}$ N.E. Morton, Teutonic Knights in the Holy Land (Woodbridge, 2009), p. 205; Deutschordens-Zentralarchiv Hs. 427C, fol.15v.

${ }^{28} \mathrm{Mol}$, pp. 27-28.

${ }^{29}$ Oorkondenboek Gelre en Zutphen IV, no. 1230.09.28.

${ }^{30}$ OSU II, no. 814.
} 
required. ${ }^{31}$ Sweder donated a house and homestead near Saint Gertrude's parish church, just outside the city wall, where the convent could be built. He also donated a small piece of land nearby, as well as "omnes areas" he possessed in Gein, a bit further south. The charter gives no indication of the size of the last category. Traces of these possessions in other sources are very scarce. In the oldest lease registers of the commandry from the 1360s, we find two small rents in Gein. ${ }^{32}$ In other words, the donation's foremost purpose was to give a piece of land that was suited for the construction of the convent buildings. We may add to these goods the piece of land in Schalkwijk that Sweder Senior had given in 1219. Still, a homestead and a few pieces of land could not have possibly been enough property for the Teutonic House to start with. There are goods missing in our reconstruction.

A second question concerns the crusade vow of Sweder Junior and Beatrix. Which expedition did they refer to? Form a chronological point of view, the Sixth Crusade, in which Emperor Frederick II crowned himself King of Jerusalem, may be an obvious candidate, but we can rule out this option since it only had a small number of participants from the Low Countries. Besides, it was not the mass expedition that the siege of Damietta had been, and women were explicitly excluded from participation. ${ }^{33}$ Another possibility is the expedition of the Teutonic Knights in Prussia that started with the building of the castle Vogelsang at the banks of the Vistula in 1230. However, there are no reports on the participation of crusaders from the Low Countries in the military Order's activities at that time there.

\footnotetext{
${ }^{31}$ U. Arnold, 'De Duitse Orde als economische factor in Noord-West-Europa tijdens de middeleeuwen', in Crux et arma. Kruistochten, ridderorden en Duitse Orde, ed. J. Mertens, Bijdragen tot de Geschiedenis van de Duitse Orde in de Balije Biesen, 4 (Bilzen, 1997), pp. 155-156.

${ }^{32}$ Archief van de Ridderlijke Duitsche Orde Balije van Utrecht, no. 646-1.

${ }^{33}$ Morton, p. 46; H. Hardenberg, De Nederlanden en de kruistochten (Amsterdam, 1941), pp. 181-182.
} 
Moreover, the bishopric of Utrecht at the time had his own battles to wage. In 1227, tensions in the eastern parts of the bishopric led to the outbreak of a rebellion, which Bishop Otto of Lippe intended to quell during the summer. From eyewitness accounts we get the impression that he took a large army of ministeriales with him. The expedition bore some resemblance to a crusade, with the enemy described as "not humans, but ferocious animals." ${ }^{34}$ The battle ended in one of the most infamous events in the bishopric's history. In marshy terrain near the village of Ane, the bishop was caught, scalped, and then brutally killed. The episcopal troops were massacred. The next bishop, Wilbrand of Oldenburg, defeated the rebels in an expedition that took place in 1231 . This time, the crusade format was explicitly followed, with indulgences given to the participants. ${ }^{35}$

To get an idea of Sweder Junior's position in the conflict, we need to turn our attention again to his patronage relations. Whereas Sweder Senior probably became a ministeriale in Utrecht, his son certainly quickly climbed the social ranks in the service of the bishop. In 1225, Sweder Junior was named the city's sheriff, one of the highest public offices in the bishopric. It is tempting to see this appointment in the context of the clientelist policies of Bishop Otto of Lippe given that both men belonged to the group of confidants of Theodore of Are that immigrated to Utrecht early in the century. In March 1227, Sweder Junior was still sheriff. By November, however, he had lost this honourable position to Gerard of Merlo. One year later, Sweder is mentioned once as an ordinary ministeriale, in an event that involved the Bethlehem monastery. ${ }^{36}$ Thereafter, he left Utrecht to find patrons elsewhere. Together with Count Herman of Lohn, his brother in law, he was present at the

\footnotetext{
${ }^{34}$ Quedam narracio, pp. 48-49.

${ }^{35}$ Quedam narracio, pp. 76-81.

${ }^{36}$ OSU II, nos. $737,757,772,784$.
} 
conclusion of an alliance between Count Theodore of Cleves and Bishop Ludolf of Münster in 1231. ${ }^{37}$ Until Sweder Junior's death, somewhere between 1245-1247, he remained in the vicinity of the Count of Cleves. ${ }^{38}$ In 1243, he also became a vassal of Count Otto of Guelders, and promised to stand at his side against everyone except the Bishop of Münster and the Count of Cleves. ${ }^{39}$ Utrecht was clearly no longer in sight.

Sweder Junior's rapid removal from Utrecht thus set in between March and November 1227. Right in the middle of that period, the revolt in the eastern part of the bishopric took place. A major loyalty problem unfolded for him. The most distinguished ministeriales were expected to assist the bishop. We may assume that Sweder Junior, together with his wife Beatrix, took up a vow for this regional crusade. In one chronicle that reports on the events, a "Theodericus de Tinghede," probably a relative of Sweder, is listed between the victims on the bishop's side. ${ }^{40}$ However, Sweder Junior also had close connections with the rebel's camp, since they came from the eastern side of the bishopric, close to his hometown of Dingden. In another account, the county of Lohn, where his fatherin-law was count, is listed as part of the rebel's side. ${ }^{41}$ It is likely that in these circumstances, Sweder and Beatrix chose not to take part at all. We do not know exactly how this decision

\footnotetext{
${ }^{37}$ Westfälisches Urkundenbuch III: Die Urkunden des Bistums Münster 1201-1300, ed. R. Wilmans (Münster, 1871), no. 292.

${ }^{38}$ Reigers, pp. 254-255; Urkundenbuch für die Geschichte des Niederrheins II, nos. 258, 265.

${ }^{39}$ P. Bondam, Charterboek der hertogen van Gelderland en graaven van Zutphen I (Utrecht, 1789), nos. 40-41.

${ }^{40}$ Een cronike van den greven van Benthem. Edition und Übersetzung einer spätmittelalterlichen Chronik über die Grafen von Bentheim, ed. F.H. Roolfs, H. Riedel-Bierschwale and V. Honemann (2 ${ }^{\text {nd }}$ edition, Bielefeld, 2011), pp. $59,87$.

${ }^{41}$ Quedam narracio, p. 47.
} 
was received, but it can be assumed with some certainty that someone suspected of having sympathy for the rebels would no longer have been eligible for a high legal office. This conflict of interest was the primary cause for his quick departure from Utrecht. In Dingden, at a safe distance from Utrecht, Sweder Junior assigned possessions he left behind to the Teutonic Order. This explains why not a single name from Utrecht appears on the witness list. He also expressed his new status by calling himself miles of his newly built Ringenberg castle. Borderlord Sweder had found new patrons.

\section{Composing Property for a Teutonic House in Utrecht}

The quarrelsome 1220s in the bishopric of Utrecht form one reason why plans to establish a settlement for the Teutonic Knights in the wake of the Fifth Crusade were difficult to materialize. The regional "crusade" of 1227 and its dramatic outcome created a new momentum to bring these plans to life. Within a short period of time, men from the social standing of ministeriales and knights participated in two crusading expeditions, which resulted in many casualties. These deaths needed to be remembered and the survivors deserved to be honoured for their bravery. Usually, a religious institution took on these responsibilities. So, after Bishop Willibrand defeated the rebels, he founded the monastery of Mariënberg in 1233, close to the site where the losses had taken place, in remembrance of the ones who had died there. ${ }^{42}$ But among the many collegiate churches and monasteries in and around the city of Utrecht, there was no institution that was dedicated to the knightly ministeriales. This was due in part to their legal unfree status, which, in the past, excluded them from monastic life; but the ministeriales' rising social standing made this a very outdated hindrance in the thirteenth century. Sweder of Dingden Junior was certainly not

\footnotetext{
${ }^{42}$ OSU II, no. 859-860.
} 
the right person at this time to rectify the shortcoming by founding the Teutonic House on his own. We also saw that his donation was not large enough to achieve that. How, then, did the founding take place and who was involved?

Two charters from the 1230 s point to other stakeholders. In July 1232 , Henricus, the Order's magister de Partibus Inferioribus, accepted a donation from Albert Visser and his wife Fementia. These burghers from Utrecht conferred 42 fields ("agri") to the Teutonic Knights in order to advance the salvation of the souls of their ancestors. ${ }^{43}$ This large number of fields points to a contiguous complex of relatively small rectangular parcels that were still in the commandry's hands later in the Middle Ages. The property had a large estimated size of about fifty hectares and was within a walking distance, about one kilometre, from the spot where the Teutonic House was established.

At first sight, the social background of Albert and Fementia differs from that of the knightly benefactors of the convent. However, landownership was a common way for aristocratic burghers to align themselves with the nobility. ${ }^{44} \mathrm{~A}$ donation to the Teutonic Order was another way to integrate with the intermingling group of knightly ministeriales and lesser nobles. This desire is more explicitly present in Henricus' invitation for the couple to "come over" to the Order if they wished. Either way, they were allowed a place in the Order's cemetery, a clause which reveals that the Teutonic House had a graveyard, or at least was planned to have one.

\footnotetext{
${ }^{43}$ OSU II, no. 840; ARDOBU I, no. 196.

${ }^{44}$ M. Damen, 'The knighthood in and around late medieval Brussels', Journal of Medieval History, 43 (2017), pp. 256-257.
} 
The second charter contains an episcopal approval in 1235 of the sale of a mansus by Herman Ouderidder. ${ }^{45}$ His last name, translated as "Old Knight," is telling. The family serves as an example of successful ministeriales who, during the thirteenth century, ascended into the city's aristocracy. ${ }^{46}$ Herman is named alderman of the city in sources from 1227 onwards. ${ }^{47}$ This means that, at the time of Sweder of Dingden Junior's donation in 1231, Herman was a ministeriale in the judicial college that Sweder Junior had presided over until 1227. His vasallitic relation with the bishop is also expressed by the fact that he held the property he sold to the Teutonic House in fee from both the bishop and the castellans of the defensive castle Ter Horst, who were also ministeriales. For that reason, the approval of the sale by both parties took place at the castle. The actual sale probably happened earlier because we suspect the castellans, including men from further away like Egbert of Groningen, did not come to the castle for this specific event. It is more likely that the bishop and the castellans waited to issue the charter until they were at the castle for another occasion.

The bishop's role in the founding phase of the Teutonic House can be further understood when we locate the sold property on the map. In the charter, the site is described as "ultra Rhenum prope Trajectum." The influent of the Rhine that is referred to here can only be the trajectory that, in the sixteenth century, was no longer a waterway but, rather, the previously mentioned cart road that ran along the old Teutonic House. Analogous

\footnotetext{
${ }^{45}$ OSU II, no. 883.

${ }^{46} \mathrm{~K}$. van Vliet, 'De stad van de burgers (1122-1304)', in 'Een paradijs vol weelde'. Geschiedenis van de stad Utrecht, ed. R.E. de Bruin, P.D. 't Hart, A.J. van den Hoven van Genderen and A. Pietersma ( $2^{\text {nd }}$ edition, Utrecht, 2003), p. 107.

${ }^{47}$ OSU II, nos. 772, 806, 824.
} 
with this development, the vernacular name of the area changed from Overrijn ("overRhine") to Lijnpad ("Line path"). ${ }^{48}$ Several large fields in a row, all mansi of around ten to fifteen hectares, were located at this site, in between the place where the Teutonic House was built, and where the land donated by Albert Visser and his wife Fementia was, thus connecting the two properties with each other.

The lease registers of the Teutonic House from 1366 show that the brethren not only possessed the mansius they bought from Herman Ouderidder, but also owned the surrounding fields as well. The charters concerning the acquisition of these goods are lost, if they ever existed. Therefore, it is possible that these goods were part of the acquisitions in the founding phase as well. This core property of the convent is described in the lease registers as the estate the brethren used to exploit themselves. The exploitation method was changed to lease, probably when the new Teutonic House within the city walls was built shortly after 1345 , but it always remained a unity with only one or two tenants. A map from 1645 shows the estate was organised as a mixed agricultural domain, with a central farmstead, orchards, grain, and pasture fields. ${ }^{49}$ Although exploitation forms changed, the organisational structure as one domain remained largely unchanged.

This continuity did not arise with the founding of the Teutonic House. With the majority of the fields laying on the banks of the Rhine within the boundaries of the city's jurisdiction, they must have been cultivated before the massive peatland reclamations in the eleventh century started. At a certain point, the land became the property of the bishop.

\footnotetext{
${ }^{48}$ H.J.A. Berendsen, De genese van het landschap in het zuiden van de provincie Utrecht, Utrechtse Geografische Studies, 25 (Utrecht, 1982), pp. 167-168; G.J.A. Bruynel, ‘De derde meander. De geografische situering van de rivierlopen rond de stad Utrecht', in Jaarboek Oud Utrecht (2001), pp. 9-11, 14-17.

${ }^{49}$ Archief van de Ridderlijke Duitsche Orde Balije van Utrecht, no. 899.M.
} 
Charles Martel's donation of the castrum of Utrecht to Saint Martin's Church of Utrecht in 723 may have been that occasion. ${ }^{50}$ This assumption is based on the diverse rights the bishop had on this estate. Every time goods were transferred to the Teutonic Order here, it appears that the bishop could claim rights to them. Firstly, he enfeoffed Albert Visser and Fementia with the land they donated in return for a payment of one hundred pounds in the form of a loan. The bishop, then, retained the option to claim rights (ownership) to the land if he paid back the loan to Albert and Fementia. Apparently, he never exercised that option because centuries later the Teutonic House still owned the land as an allodium. According to one of the two remaining copies of the charter (the original version is lost), Albert and Fementia made this deal with Bishop "O." This can only can be Otto of Lippe, who died in 1227. It is possible that he made the deal with the wealthy couple to finance his crusade. As we have seen, Herman Ouderidder held the property he sold to the Teutonic House in fealty to the bishop as well. Furthermore, the lower jurisdiction and tithes of an adjacent area were possessed hereditarily as an episcopal feodum by a family with the telling name Overrijn. Theodore of Overrijn sold these rights in 1366 to the Teutonic House, thereby ending the feudal relation with the bishop. ${ }^{51}$

It is possible that Sweder of Dingden Junior held the goods he donated to the Order in 1231 in fealty as well. The location of the site next to the estate, of which it may have been part, is one cause for this suspicion. Moreover, belonging to his function as a higher ministeriale, and especially as city sheriff, was a feodum. ${ }^{52}$ When Sweder Junior left the

\footnotetext{
${ }^{50}$ OSU I, no.35.

${ }^{51}$ ARDOBU II, nos. 322-328.

${ }^{52}$ A.L.P. Buitelaar, De Stichtse ministerialiteit en de ontginningen in de Vechtstreek (Hilversum, 1993), pp. 52-

53.
} 
Utrecht ministeriality, these goods reverted back to his overlord, the bishop. Despite the lack of hard evidence for this part of the reconstruction, we have enough reasons to conclude that the founding of the Teutonic House occurred in conjunction with the compilation of contiguous landed property for the convent in which several stakeholders where involved. The estate was probably a former manor of Saint Martin's Church of Utrecht. The bishop consented that his fiefs there were transferred to the Teutonic Order. Thereby, he renounced his feudal rights, as it was impossible for a religious institution like the Order to fulfil the military duties that belonged to vassality. In this way, the bishop at least cooperated from behind the scenes in the founding of the Teutonic House.

This raises the question of whether the bishop was proactively involved in the founding process. Was he, for example, steering his vassals with fiefs in Overrijn towards donations to the Order? It is hard to gauge his exact attitude towards the Teutonic Order, but we are able to get a general impression. The earliest traceable moment in which the bishop had direct contact with the knights was during the Fifth Crusade in Damietta. Otto of Lippe was a crusader there. ${ }^{53}$ He must have known about the presence of his ministeriales at Sweder Senior's donation of 1219. Moreover, in a charter that was hitherto unknown, he confirmed the legitimacy of the donation of Count Adolf of Berg in $1218 .{ }^{54}$ Thereby, he engaged in a dispute that arose around Adolf's charter, which has been preserved in both a quite summary and a more elaborate version. In the latter version, the scope of the donation is listed..$^{55}$ This was not a superfluous addition at a time in which Pope Honorius III

\footnotetext{
53 J.J. van Moolenbroek, Nederlandse kruisvaarders naar Damiate aan de Nijl. Acht eeuwen geschiedenis en fantasie in woord en beeld (Hilversum, 2016), pp. 38-40.

${ }^{54}$ Historisches Archiv der Stadt Köln, Acc. 1439, Best. 234 (Katharina ((Deutscher Orden)), U1/2.

${ }^{55}$ ARDOBU II, no. 462; Urkundenbuch für die Geschichte des Niederrheins II, no. 72.
} 
repeatedly commissioned his church officials to safeguard the rights and possessions of the Teutonic Knights. ${ }^{56}$ Bishop Otto thus acted as protector of their new settlement within his diocese, but outside the prince-bishopric of Utrecht. In 1224, he also granted the them a privilege concerning a toll-free passage on the Rhine. This, however, must not be seen as a sign of his special sympathy for the Order because by issuing the charter he only played his part in a collective effort by princes at the Rhine. ${ }^{57}$ Still, these actions reflect a benevolent attitude towards the Teutonic Knights. Any plans to establish a settlement for them in Utrecht in the wake of the Fifth Crusade were surely not hindered by him. Moreover, we have seen that he probably drafted the feudal land tenure construction with Albert Visser and Fementia. It remains a possibility that he was involved in the process of collecting property for the Teutonic House, but was unable to materialize his part of the project before his sudden death in 1227.

His successor, Willibrand of Oldenburg, was an enthusiastic promotor of religious institutions. In particular, he became patron of the Cistercian nuns of Saint Servatius in Utrecht. He even arranged to be buried at their monastery. ${ }^{58}$ His only charter that was directed to the Teutonic Order, and that has been preserved, is an affirmation in 1232 of his predecessor's toll privilege from 1224, in similar words. ${ }^{59}$ Nevertheless, it is beyond doubt that he favoured the Order. In his former position as canon of the cathedral chapter in Hildesheim, he met Herman of Salza in 1211 while leading an expedition to the Holy Land in preparation for a future crusade. Willibrand afterwards wrote his Itinerarium Terrae

\footnotetext{
${ }^{56}$ ARDOBU I, nos. 9-29, 34-39, 42, 44-46.

${ }^{57}$ Ibid., no. 4; Codex diplomaticus Ordinis Sanctae Mariae Theutonicorum I, nos. 66, 377.

58 J.J. van Moolenbroek, 'Servatius en Johannes', Jaarboek Oud Utrecht (1997), pp. 171-174, 194-195.

${ }^{59}$ OSU II, no. 847.
} 
Sanctae. In the prologue, he praises his travel companions in general and the "honourable" grand master in particular. ${ }^{60}$ After his election as bishop of Utrecht, he first succeeded in defeating the rebels. Soon after order was restored in the bishopric, the Teutonic House was established. As we have already seen, Willibrand cooperated in this.

\section{Adjusting the Land Use Plan for the Settlement of the Teutonic Knights}

Besides the regional crusade of 1227 , there were other factors that easily could have delayed the establishment of the Teutonic House. In the first place, in the urban society that Utrecht was, there surely was opposition against the plans. It is obvious that the local Hospitallers must have been unhappy with another military order settling in. The rivalry between the two orders should not be overstated though. The brethren of Saint John in Utrecht concentrated on caring for the sick in their hospital, and had no military branch. ${ }^{61}$

The Teutonic House of Utrecht, on the contrary, was founded in the context of the crusades and attracted mainly knightly ministeriales. Both in profile and in societal origin of its members, the two seem to have had only a limited overlap. It is possible that the Hospitallers enforced some kind of division of tasks, but there is no proof that could either support or reject this claim.

City dwellers may also have offered resistance. Because of the many monasteries that were established in the city since the twelfth century, a large number of buildings and landed property was gradually transferred into the hands of the clergy. In itself this was not

\footnotetext{
${ }^{60}$ Wilbrand of Oldenburg, Itinerarium ... Terrae Sanctae, ed. D. Pringle, 'Wilbrand of Oldenburg's journey to Syria, Lesser Armenia, Cyprus and the Holy Land (1211-12): A new edition', Crusades, 11 (2012), pp. 109-116.

${ }^{61}$ J.M. van Winter, 'Heren van Sint-Catharijne te Utrecht', in Bewogen en bewegen. De historicus in het spanningsveld tussen economie en cultuur, ed. W. Frijhoff and M. Hiemstra (Tilburg, 1986), pp. 350-353.
} 
necessarily problematic, as long as religious institutions created jobs for lay civilians and as long as there was still enough space left in the city for their homes. The latter factor might have played a role in choosing the location where the Teutonic House could be built, just outside the city walls. However, building in open spaces in the city and dividing larger parcels into smaller ones was a practice that was only in its infancy in Utrecht in the first half of the thirteenth century, and even continued during the fourteenth century. ${ }^{62} \mathrm{~A}$ lack of space, therefore, was not an urgent issue in 1231.

Potentially more problematic were the consequences of new institutions for the city's public finances. As the clergy enjoyed tax exemptions and other privileges, the tax burden predominantly fell to the lay burghers. Yet, per capita, they may have experienced decreasing taxes, because the expanding clergy coincided with a growing population of the city from an estimated 3000 at the beginning to about double that number at the end of the thirteenth century. A clear sign that the city treasury was anything but empty, are the major building projects that were undertaken. Certainly, the largest two of these were the tall Gothic cathedral tower, started directly after a fire in 1253 , and, earlier in the century, the beginning of the replacement of the earth wall around the city by stone walls. ${ }^{63}$ The fact that the Teutonic House was a religious institution thus did not deter aristocratic burghers like Albert Visser and Fementia from supporting it.

The growth of the city and the many building projects did affect the founding process of the Teutonic House in another way. The location of the convent was, in the words of

\footnotetext{
${ }^{62}$ M. Dolfin, E.M. Kylstra and J. Penders, Utrecht. De huizen binnen de singels. Beschrijving (Zeist, 1989), pp. 1315.

${ }^{63}$ Vliet, pp. 95-99.
} 
Sweder of Dingden Junior when he donated it in 1231, "ad sanctam Geertrudem in Trajecto." This parish church was named after the early medieval saint, Gertrude of Nivelles. What could the involvement of this neighbour have been when the Teutonic Knights suddenly became the largest land owner next door, and perhaps even within the parochial boundaries?

Saint Gertrude's church was part of three urban parish churches that were built in the second half of the twelfth century. At that time, one parish church could no longer serve the growing population of the city. A distinction was made between this centrally located church and the three new ones. They were built at the edges of the city, so that they could attract the residents living in the surrounding countryside. Saint Gertrude's church thus served an urban settlement in the southwestern corner of the city as well as the adjacent agricultural areas, like Overrijn. ${ }^{64}$ The location on a river bank at the city side of the river made sense at the time of building, especially if it replaced an older chapel that outdated the city wall of earth while a still flowing Rhine was a natural border. But the construction of a stonewall at the other side of the church made the place vulnerable. If this church had a tower that was higher than the wall, it also posed a threat from a defensive point of view. Therefore, between 1248 and 1255, the church was torn down and rebuilt in a safer place, in the part of the parish that laid within the city walls. A few years later, the former churchyard was transferred to the Teutonic Knights. ${ }^{65}$

\footnotetext{
${ }^{64}$ M. de Bruijn, 'De "vicus Tastcunt": Het gebied ten noorden van de Geertekerk', Maandblad Oud-Utrecht, 56 (1983), pp. 244-245.

${ }^{65}$ OSU II, no. 1175; OSU III, nos. 1349, 1510.
} 
These knights were now able to fulfil their promise to Albert Visser and Fementia, to reserve a place for them in the Order's graveyard. This promise was not given without an idea of how to effectuate it. We may suggest that there is a causal link between the move of the Saint Gertrude church and the settlement of the Teutonic House on its former site. The question of the church's unfortunate location was certainly considered when it was decided that the Teutonic Order could build a settlement next door and receive a large portion of the land within the parochial boundaries. The most powerful church official to be involved in negotiating this trade-off was the provost of Saint Martin's Cathedral. This 'second man' of the bishopric exercised the patronal rights over the city's parish churches. Otto of Lippe held the office until he was elected bishop in 1216. In sources from 1226 until 1232, Theodore of Randerath is called the provost. Thereafter, he returned to Cologne. We already encountered this man as one of the immigrants mostly from the Rhineland who came to Utrecht in the footsteps and under the patronage of bishop Theodore of Are. Otto of Lippe, Gerlacus of Dingden, and his uncle Sweder Senior belonged to this group as well. In the years between the Fifth Crusade and the founding of the Teutonic House, this circle of confidants pulled the strings in the city. This enabled them to implement or influence large building projects.

An example of such a project concerns the aforementioned nuns of Saint Servatius. Their monastery was established in the 1220s, after the Fifth Crusade, under the episcopate of Otto of Lippe. It was initially built in Abstede, southeast of the city, but within its judicial area. The religious women were also given a large landed estate there. In 1241, the bishop granted them exemption from the several taxes he levied in what he called the curtis of Abstede. Eight years later, they bought the tithes of the area, which were a fief of the cathedral's provost. The agrarian settlement of Abstede presumably was a former manor of 
Saint Martin's Church of Utrecht. Thus, the bishop was involved, to say the least, in creating a core property for the nunnery of Saint Servatius, thereby enabling its founding. ${ }^{66} \mathrm{His}$ successor Willibrand continued favouring the nunnery with donations and by organising the re-housing of the convent to a place in the city; hence, his burial there. In the meantime, it became an abbey when the nuns, who followed the rule of Saint Benedict, embraced the Cistercian order. This move may already have been made under Bishop Otto. ${ }^{67}$ In other words, Willibrand carried on or scaled up the project that was started by Otto.

To sum things up using modern concepts, the land use plan of the outlying parts of Utrecht was completely renewed. The city border was hardened by replacing the earth wall by a version of stone. Furthermore, Saint Gertrude's church was rebuilt on a site within these walls. In cooperation with the bishop, remnants of church domains in Abstede and Overrijn, both on the surrounding countryside that fell under the jurisdiction of the city, were reshaped as core estates of the newly-founded Saint Servatius' abbey and the Teutonic House, respectively. Whereas both convents were built next to their estate, the first was quickly moved to a safer place in the city. Soon came the initiative to re-house the Teutonic Knights as well. In 1250, the bishop and the provost of Saint Martin's Cathedral together gave them Saint Nicholas parish church and granted permission to build a new convent next to it. However, this decision was contested. Even support from the famous Albertus Magnus could not prevent its eventual cancellation. ${ }^{68}$ The Teutonic House remained on its original location until it was destroyed in 1345 when the count of Holland laid siege to the city.

\footnotetext{
${ }^{66}$ M.P. van Buijtenen, 'De St.-Servatius-abdij en Utrechts stadsuitleg', Archief voor de geschiedenis van de katholieke kerk in Nederland, 13 (1971), p. 329; OSU II, no. 962.

${ }^{67}$ Moolenbroek, 'Servatius en Johannes', pp. 90-92, 171-174, 194-195.

${ }^{68}$ OSU III, nos. $1218,1240$.
} 


\section{Conclusion}

The founding history of the Teutonic House of Utrecht had always been based on just a few preserved primary sources. This resulted in an overly simplified picture of the convent's establishment by Sweder of Dingden Junior in 1231. By placing these sources in their social and political context, we were able to tell a more nuanced story in which we discovered the complexity of the founding process. We also identified several stakeholders in the operation.

This revisited story starts with a wider political context and specifies from there to local events in Utrecht. The early thirteenth century was a very quarrelsome time in the Low Countries. Tensions were enlarged by the dispute over the German crown between the Hohenstaufen and Welf dynasties. Existing alliances and patronage relations were put under pressure, resulting in several regional armed conflicts like the crusade against rebels in the bishopric of Utrecht. It was mainly Pope Honorius III who strived to maintain internal peace in the region by preaching the cross against an external enemy. This method worked; many crusaders from the Low Countries travelled to Damietta in the Fifth Crusade.

These bellicose times stimulated the social rise of knights who, in Utrecht, were predominantly ministeriales. They aligned themselves with nobles with princely aspirations in the periphery of larger principalities, who started to call themselves knights as well. This merger worked the other way around as well. Knightly ministeriales of the bishop of Utrecht began to attain noble features, for instance, by using the title dominus. They also began to commit themselves to a religious institution. The Teutonic Order was pre-eminently the right military order for them.

In Utrecht, the two Sweders of Dingden - Senior and Junior - contributed substantially to the founding of a settlement of the Teutonic Order. They participated in a patronage network consisting of local knightly ministeriales and a group of Westphalian 
immigrants holding posts in the ecclesiastical elite since the early thirteenth century. Among this network, plans were made to establish a settlement of the Teutonic Order in Utrecht during the Fifth Crusade. But, in an urban context, these plans were harder to materialize than in rural areas, where most of the other convents of the Order in the Low Countries were established at that time.

The plans gained momentum as the regional crusade of 1227 turned into a fiasco for the bishop and his entourage. With a sense of urgency, people from outside the knightly ministeriality were willing to cooperate in finding a suitable place for the Teutonic House and its necessary landed estate. In the context of a larger reform of the land use plan in the city's agricultural outer zone, parts of a former manor of Saint Martin's Church of Utrecht were reunified to compile such an estate for the convent. There were several stakeholders in this operation, among whom the provost of Saint Martin's Cathedral, but especially the bishop, as feudal lord of the manor, played a steering role in achieving the founding of the Teutonic House in Utrecht. 